ドとして動画像表示する手術支援を行っている．今回われわれは雨 手法における適正な描出について検討を行った.

【方法】色素法SLNBが施行され, SLNが同定された乳癌患者を対象と した. retrospectiveな検討として, SLNを含む腋窩リンパ節のCT值を 測定した。またMPVRの厚さ設定(スラブ厚)を3-40mm程度変化さ せ、リンパ節描出を両手法間で比較した。

【結果】MPVRとVRの両手法ともSLNは描出された。CT値は単純CT で約 $0-50 \mathrm{HU}$, 造影CTで10-150HUの範囲であった. MPVR設定厚 が厚くなると構造物の重なりが生じ, 前後の位置関係(術者から観て 深さ)の把握が困難になる場合がみられたが, $10 \mathrm{~mm}$ 厚以下では構造 が分解されて描出された。またVRでは閾值設定によってリンパ節の 大きさが変化するため, オパシティカーブ設定時には対象物の閾值 について考慮する必要があった。

【結語】色素法SLNBに扔いて, 術中に三次元構造を立体的に迅速簡 便に把握するにはVRが適していた。しかしVRで重なりがあって奥 側が観察できない場合, リンパ節CT值が低い場合, リンパ節サイズ が小さい場合などにはMPVR情報の付加が有利と思われた。

\section{6 䁂移植術前検査としてMDCTの有用性}

東京慈恵会医科大学附属病院・放射線部 竹沢 均，朝田慎介

石崎雅俊，關 義晃，天野善之，矢本俊一

【目的】従来，腎臟移植手術前にドナー, レシピエントとも血管の走 行, 奇形, 石疢化の有無を確認するためDSAを施行していた。近年 MDCT(Multi Detector-row CT)の普及により簡便に血管走行が描出で きるようになり，ドナー，レシピエントの検査時間の短縮，負担が 軽減できる.今回，われわれは簡便な手法としてMDCTの腎移植術 前検査プロトコルを作成し，その有用性について検討した。 【方法】使用装置：SOMATOM sensation4(4DAS-CT.SIEMENS社製). ドナー：造影剂イオパミドール370/100mlを使用, $120 \mathrm{kv}, 140 \mathrm{mAs}$ 撮影. 造影前に石灰化, 結石の確認, Artery PhaseでMIP, MPRを作 成，MDCT検査終了後に尿管走行描出のため腹部エックス線撮影を 施行.レシピエント：イオパミドール $300 / 100 \mathrm{ml}$ 使用, $120 \mathrm{kv}$, $140 \mathrm{mAs}$ で撮影造影前に石灰化の確認, Arterial Phaseで 3-D, MIPを 作成，Venous PhaseでMIPを作成。

【結果考察】DSAを施行した場合, 止血等でオバーナイト入院は避け られないが，今回のプロトコルによりドナー，レシピエント共に 20 分弱で検査が終了する．ドナーの撮影についてケアボーラス $80 \mathrm{HU}$ らディレイタイム14secに設定し腎動脈, 腎静脈が描出され，1相の みで診断を可能にした．また尿管の走行を確認するため 5 分後に尿 路CTを検討したが, 被ばく線量を考慮し, エックス線写真とした. レシピエントの撮影については透析期日を考慮し, 検査を施行し た.

\section{MDCTによる下横隔膜動脈の描出法の検討}

石川県済生会金沢病院·放射線部 奥村悠祐, 鈴木正行, 武村哲浩 金沢大学·医学部保健学科 高田忠徳, 辻井秀夫

【目的】Right inferior phrenic artery(RIPA)は繰り返しTAEが行われた 症例において肝癌を栄養することがある。今研究の目的は, multi detector computed tomography (MDCT) を用いた通常の腹部造影検査 で得られた画像データから multi planar reconstruction(MPR)を用いる ことによってRIPAの走行を描出することである.

【方法】MDCTを用いて $2.5 \mathrm{~mm}$ スライス厚のデータが得られている腹 部造影CTのうちで，RIPAが腹腔動脈から起始し，血管造影で同定 されている11症例(男性 8 名, 女性 3 名: $52-79$ 才, 平均65才) を対 象とした，得られたCT画像データから三次元再構成を行い， RIPA の走行が観察できるような三次元画像を作成した，腹部血管造影で 得られた画像を golden standardとして，作成した三次元画像において RIPAの起始部や走行の様子について比較, 検討した.
【結果】全ての症例でRIPAの走行を描出することが可能だった。しか し，1例で起始部を描出することができなかった

【考察】RIPAは右横隔膜下を肝臓の背側に沿って肝臓の後上区に向 かって上行する，その走行は直線的ではないため，一つの画像で全 ての走行を描出させるのは困難である。しかし，数枚のMPR像を組 み合わせることにより走行を描出させることが可能であった．RIPA の起始部が描出できなかった症例では元画像においても起始部を同 定できなかった。しかし，走行の状態から容易に腹腔動脈起始と予 想することができ, 血管造影の走行とも一致した.今回の検討で, RIPAの走行をMPRで描出することが可能であり，作成した画像は TAE前の有用な情報を提供すると考える.

\section{8 三次元 CT門脈画像の描出能の評価一造影剂浸透圧の評価に} วいて-

広島大学病院 ·診療支援部 井澤伸尚, 石風呂実, 藤岡知加子

木口雅夫，山岡秀寿，古川隆志，玖島利男

【目的】現在, MDCTの多列化は三次元ボリュームデータをより高分 解能に取得し多様な画像情報を提供している。 その中でも三次元画 像は重要な位置づけにあり，形態診断および手術計画などに応用さ れることが多くなった，今回我々は，肝Dynamic Studyが必要とされ るHCC等の肝疾患症例と生体肝移植の正常例すべてにおいて 2 種類 の造影剤浸透圧の違いによる門脈の造影効果について評価した。

【使用機器】CT装置 : Light Speed Ultra 16(GE), 画像解析装置 : Virtual Place(AZE), CT用自動注入器：デュアルショット(根本杏林 堂), 造影剤：300mgI(イオメロン, オムニパーク)

【方法】造影剂濃度およびヨード投与量を一定とし, 浸透圧 $\left(520,680 \mathrm{mOsm} / \mathrm{kg} \mathrm{H}_{2} \mathrm{O}\right)$ の違いによる門脈の造影効果の評価を得るた めに, 撮像法を固定とした注入固定法を用いて動脈早期相, 動脈後 期相, 門脈相の造影 3 相で血管のCT値を解析した.

【結果および考察】第61回の総会において三次元CT門脈像の造影効果 は体重あたりのヨード投与量を一定にした場合, 低濃度造影剂を投 与した場合良好な結果となったが, 今回, 濃度一定で浸透圧別では 一部の症例においては浸透圧の低い造影剤を用いた場合, 門脈の造 影効果が良好であった症例を認めた. しかし, 双方ともに浸透圧に よる有意差は得られなかったが漫透圧の低い造影剤は造影効果を上 げる傾向にあったままた, 門脈の造影効果を行うためには体重別よ りもBMIでの評価法が望ましかった。

369 頭部単純CTにおける容積データの有用性：アルツハイマー 型痴呆を主とした認知症の進行度判定の可能性

順天堂練馬病院・放射線部 木暮陽介

順天堂東京江東高齢者医療センター・放射線科 高瀬 誠

【目的】MDCTの登場により，造影剂を用いたスタデイおよび肺野や 管腔臓器といった高コントラスト領域での容積データの活用法は目 覚しい進歩をとげている. しかし, 頭部単純CTにおいては, 空間分 解能の劣化懸念とAxial image以外の有用性報告の少なさからnonhelical scanで撮像しているケースが多い. 今後, 多列化に伴った容 積デー夕使用のインターフェース構築においても, 頭部単純CTでの helical scanの有用性を示唆する必要があると考えた。第 1 報では, 2020 年には65歳以上人口の有病率が $8.9 \%$ と試算され, 要介護認定な どの社会的道義も求められる認知症に対して, MDCTを用いた容積 データが有用であるかを検討したので報告する.

【方法】1)GE社製 LightSpeed Ultra 8 列において，QAファントムを用 いて最適な条件を検討した．2)対象はNINCDS-ADRDA診断基準に て鑑別された, アルツハイマー型痴呆群15名(平均76.3歳)と非アル ツハイマー型痴呆群 15 名 (平均73.8歳) (全30症例が認知症と診断され ている)とした．3）画像計測を行い，6つの指標(側脳室下角横径· 側頭葉内側径 ·鈎間距離 - 側脳室体部面積 - 側脳室体部角 - 鉤溝角) 